\title{
PROFESSIONAL COMPETENCE FORMATION MODEL OF THE FUTURE BACHELORS OF FOOD TECHNOLOGIES IN HIGHER EDUCATIONAL INSTITUTIONS
}

\section{МОДЕЛЬ ФОРМУВАННЯ ПРОФЕСІЙНОЇ КОМПЕТЕНТНОСТІ МАЙБУТНІХ БАКАЛАВРІВ ХАРЧОВИХ ТЕХНОЛОГІЙ У ВИЩИХ ПЕДАГОГІЧНИХ НАВЧАЛЬНИХ ЗАКЛАДАХ}

\section{Tkachyk Stanislav ${ }^{1}$ \\ Filimonova Iryna ${ }^{2}$}

DOI: http://dx.doi.org/10.30525/978-9934-571-27-5_54

Abstract. The article describes the structural-component model of the formation of professional competence of future bachelors of food technologies in higher pedagogical educational institutions. The model suggests ways to achieve this goal on the basis of the application of various forms and methods of teaching through the implementation of pedagogical conditions.

The aim of the research is to determine and theoretically substantiate the pedagogical model of the formation of professional competence of future bachelors of food technologies in the process of studying special disciplines.

The relevance of the article is conditioned by the needs of the society in competitive specialists for vocational education and the service sector, possible when implementing a competence approach.

One of the ways to solve this problem is to model the process of forming the professional competence of future bachelors of food technologies. This will make it possible to understand the features of this process and, if necessary, to correct the individual elements.

The model of the formation of professional competence, proposed by the authors, contains three blocks. The first block - the target - highlights the goal, which is determined by the social order for professionally

\footnotetext{
${ }^{1}$ Professor of the Department of Professional Education and Technologies by Profiles,

Pavlo Tychyna Uman State Pedagogical University, Ukraine

${ }^{2}$ Postgraduate Student of the Department of Professional Education and Technologies by Profiles, Pavlo Tychyna Uman State Pedagogical University, Ukraine
} 
competent specialists, capable of future activities in vocational schools, food industry and service industries. For the effective formation of the model of professional competence of future bachelors of food technologies, the expediency of using the system, competence, research, technological, activity, personality-oriented approaches, as well as general didactic (systematic and consistency, scientific, system and accessibility, activity and independence, visibility) and specific (personal, individual educational path, educational reflection, cooperation) principles of learning, contribute to the formation of professional competence of future specialists.

The organizational and content block covers pedagogical conditions, pedagogical technologies, forms, methods and content of training future bachelors of food technologies in the process of studying special disciplines. Among the pedagogical conditions the authors identified the following: the creation of the motivational and value environment in the learning process; expansion of the cognitive-activity component of the professional training of future bachelors of food technologies through the use of interactive teaching methods; development of personal and professionally important abilities, moral perfection of the personality of the future specialist.

In the reflexive block, evaluation, analysis and correction of the results of forming the professional competence of future bachelors of food technologies are provided. It reflects the criteria (motivational, activity, reflexive), their indicators and levels of formation (low, medium, high), which makes it possible to talk about a certain level of the formation of professional competence of the future specialist.

Taking into account the results of the research and limiting ourselves to the conditions of a certain higher pedagogical institution, the authors suggest that the implementation of the pedagogical model will contribute to improving the efficiency of the preparation of future bachelors of food technologies in future professional activities in the process of studying special disciplines.

\section{1. Вступ}

Кінець XX - початок XXI століття позначився приверненням уваги до проблем професійно-технічної освіти як основи підготовки майбутніх кваліфікованих фахівців для усіх галузей виробництва. На порядку денному постало завдання реформування галузі професійно-технічної освіти у зв'язку з кардинальною зміною вимог до якості кінце- 
вого продукту. Світова глобалізація, міжнародна конкуренція, потреби національного ринку праці почали висувати нові, підвищені вимоги до кваліфікації робітників, а звідси, до змісту і форм їхньої професійної підготовки. Водночас виникла гостра необхідність у підготовці нових кадрів, пов'язана із входженням України до європейського та світового ринку. За словами Л. Гриневич: «...Глобальною валютою сьогодні називають кваліфікації. І тільки та країна, яка має кваліфіковану робочу силу, не програє в міжнародній боротьбі» [4, с. 4].

В свою чергу соціально-економічні зміни, які відбуваються в Україні, визначили нові напрями підготовки майбутніх фахівців професійно-технічної освіти. Однією з пріоритетних тенденцій удосконалення цього процесу стає компетентнісний підхід, тобто орієнтація на набуття майбутніми фахівцями певного рівня професійної компетентності вже у процесі навчання.

Тому постала необхідність пошуку нових моделей підготовки компетентних конкурентоспроможних фахівців, готових працювати в умовах оновленої освітньої системи, а також механізмів і шляхів їх реалізації.

Необхідність упровадження компетентнісного підходу пояснюється й тим, що традиційна підготовка фахівців, орієнтована лише на формування знань, умінь і навичок під час вивчення окремих навчальних предметів, все більше відстає від сучасних вимог суспільства та роботодавців. При цьому особливі вимоги ставляться саме до практичної підготовки майбутніх фахівців [8, с. 24].

У вітчизняній та зарубіжній науці налічується велика кількість наукових праць, присвячених цим питанням: загальному стану професійної освіти на початку XXI сторіччя (А. Гуржий, В. Зайчук, 3. Курлянд, А. Лаптєва, Н. Ничкало, С. Сисоєва, В. Тименко, О. Щербак та ін.), підготовці інженерно-педагогічних кадрів (Е. Зеєр, О. Коваленко, М. Лазарєв, Н. Недосєкова, Л. Тархан та ін.), формуванню професійної компетентності фахівців професійно-технічної освіти (В. Байденко, Н. Бібік, Н. Брюханова, О. Дубасенюк, В. Кремень, О. Локшина, Н. Ничкало, О. Овчарук, О. Пометун, А. Хуторський та ін.)

У своїх дослідженнях вчені наголошують на тому, що з процесом ринкових економічних трансформацій у країнах світу, і в Україні зокрема, відбулися певні переоцінки суті, призначення, функцій професійної освіти. Якщо донедавна таку освіту розглядали як простий 
засіб відтворення «робочої сили», то у сучасних умовах - це джерело активного відродження та росту економічно та соціально активних груп населення, які можуть працювати в усіх сферах суспільного виробництва.

Саме тому постає необхідність у створенні умов для прояву індивідуальності людини, становленні нового стилю її професійної діяльності, формування у майбутнього фахівця умінь самостійно визначати способи здійснення виробничих завдань, що є ознакою його компетентності. Особливо ці реалії позначаються на підготовці майбутніх фахівців-технологів у галузі харчових технологій, чия професійна діяльність зумовлена вимогами суспільства та ринком праці.

Майбутній фахівець визначеної галузі має здобути підготовку Європейського рівня, щоби бути готовим залучитися до розробки нових технологій вже на стадії навчання, бути адаптованим до умов конкретного виробничого середовища, здатним до мобілізації своїх знань, умінь і досвіду в конкретних виробничих ситуаціях, тобто набути професійної компетентності.

\section{2. Аналіз поняття «професійна компетентність»}

У сучасній науково-педагогічній літературі поглиблюються дискусії з приводу трактування професійної компетентності як педагогічної категорії. Тому на початку нашого дослідження визначимося з науковими підходами до розуміння професійної компетентності педагога взагалі та бакалавра харчових технологій зокрема.

Як зазначено в Брюгському комюніке про зміцнення європейського співробітництва у сфері професійної освіти й навчання на період 2011-2020 років, нині необхідно надати випускникові змогу опанувати компетентності, які є не тільки професійними, а й важливими для успішної професійної діяльності. Тому повинні бути створені усі можливості для засвоєння цих компетентностей у вищих педагогічних навчальних закладах [2].

Вищезазначеним напрямам реформування повністю відповідає Концепція ключових компетенцій, затверджена у 2010 р., де компетенції трактують як важливу умову конкретизації загальних цілей освіти, що дозволяє по-новому оцінити ії якість [1].

В Україні компетентнісний підхід набув поширення порівняно нещодавно у зв'язку з дискусіями про проблеми і шляхи модерніза- 
ції освіти. Основним поштовхом до цього стало входження України в Європейський освітній простір, зокрема приєднання до Болонського процесу, основними завданнями якого є розширення доступу до вищої освіти, підвищення якості освіти та ефективності використання фахівців з вищою освітою.

Як вказується у Національній стратегії розвитку освіти на 2012-2021 рр., формування та розвиток фахівця, соціально зрілої творчої особистості, громадянина України і світу можливий за умови створення ефективної цілісної системи універсальних знань, умінь, навичок, а також досвіду самостійної діяльності й особистої відповідальності, тобто ключових компетенцій, які визначають сучасну якість змісту освіти. Тому компетентнісний підхід і був покладений в основу урядової стратегії модернізації освіти [7].

Використання компетентностей в європейській освіті потребувало детального дослідження їх сутнісних характеристик. Вагомі напрацювання у цій царині зроблено науковцями Національної академії педагогічних наук України Н. Бібік, О. Овчарук, О. Пометун, О. Савченко [3, с. 48]. Основними ідеями компетентнісного підходу вітчизняні науковці вважають:

- поняття компетентності ширше поняття знання чи вміння;

- поняття компетентності містить не тільки когнітивну й операційно-технологічну складові, а й мотиваційну, етичну, соціальну й поведінкову;

- ключова компетентність $\epsilon$ інтегративною за природою, оскільки вбирає в себе низку умінь і знань, які належать до широких сфер культури й діяльності.

Відомі вітчизняні науковці Н. Брюханова, О. Коваленко, О. Мельниченко стверджують, що професійна компетентність інженера-педагога - це сукупність знань, умінь та способів виконання певної діяльності [6, с. 144].

Українська дослідниця Л. Тархан розглядає професійну компетентність інженера-педагога як якісну характеристику рівня оволодіння ним професійною діяльністю, що зумовлена глибокими знаннями властивостей об'єктів праці, вільним оволодінням засобами виробництва, здатністю виконувати складні види професійної діяльності [9, с. 15].

О. Добровольска у своїх дослідженнях визначає три напрямки формування професійної компетентності майбутніх інженерів-педагогів: 
формування особистісного стилю діяльності у результаті зміни системи виконання діяльності, іiі функції та ієрархічної побудови; становлення професійного світогляду на основі зміни особистості суб'єкта; становлення професійної культури внаслідок зміни когнітивних, емоційних і практичних компонентів установки суб'єкта стосовно об'єкта діяльності, перетворення впливу на об'єкт у процесі їх взаємодії [5, с. 8].

Отже, здійснений аналіз праць учених дозволяє нам зробити наступне узагальнення: професійна компетентність майбутнього бакалавра харчових технологій - це сукупність взаємопов'язаних якостей особистості, що передбачає досконале володіння теоретичними знаннями і практичними навичками, вміння застосовувати їх у процесі професійної діяльності, здатність творчо і нестандартно вирішувати проблеми, нести відповідальність за наслідки своєї роботи, а також професійне зростання шляхом постійного саморозвитку, самовдосконалення та самоосвіти.

\section{3. Аналіз структурних складових професійної компетентності}

Здійснений теоретичний аналіз наукових досліджень вітчизняних та зарубіжних науковців дає можливість припустити, що формування професійної компетентності майбутніх бакалаврів харчових технологій у процесі вивчення фахових дисциплін буде більш ефективним за умови реалізації структурно-компонентної моделі, що є необхідним засобом для визначення цілей освітнього процесу, способів і засобів їх досягнення, отримання належних результатів.

Для ефективного формування моделі професійної компетентності майбутніх бакалаврів харчових технологій потребує обгрунтування доцільність використання наукових підходів та загальнодидактичних і специфічних принципів навчання.

Системний підхід - комплексне вивчення процесу формування професійної компетентності майбутніх бакалаврів, виявлення взаємозв'язків і взаємодій між викладачами та студентами, реалізація якого в процесі вивчення фахових дисциплін передбачає застосування загально-дидактичного принципу систематичності та послідовності. Цей принцип передбачає засвоєння студентами навчального матеріалу у визначеному порядку таким чином, щоб наступний новий елемент іiі змісту логічно пов'язувався як з попереднім, так і з наступним його елементом. При цьому створюється фундамент для засвоєння нових знань з інших фахових дисциплін. 
Компетентнісний підхід - наявність необхідних знань, умінь і навичок, здатність самостійно їх використовувати у професійній діяльності. Цей підхід враховує загальнодидактичні принципи навчання: науковості; системності та доступності; активності й самостійності; наочності; грунтовності.

Технологічний підхід - спрямованість навчання на конкретні завдання, які окреслюють необхідний зміст навчального матеріалу, зменшуючи надмірність інформації в процесі засвоєння нових знань та реалізації викладачем об'єктивного контролю за цілісністю навчального процесу. Відповідно до мети й завдань дослідження зазначений підхід є особливо вагомим, оскільки ідентифікує шляхи реалізації інноваційних технологій у процесі практичної підготовки майбутніх фахівців.

Діяльнісний підхід в процесі вивчення фахових дисциплін передбачає застосування принципу науковості, систематичності та послідовності, активності й самостійності, грунтовності та створення спеціальних умов для практичної роботи студентів.

Особистісно орієнтований підхід - це професійно-особистісний розвиток майбутнього бакалавра харчових технологій, спрямований на формування в майбутніх фахівців не тільки знань, умінь та навичок 3 фахової галузі, але й особистісних якостей. Реалізація такого підходу можлива за умов застосування під час вивчення фахових дисциплін елементів евристичного та проблемного навчання, методу проектів, коли студент самостійно обирає форми виконання роботи, створює та розглядає можливі варіанти розв'язання завдань проекту, обирає найкращий, обгрунтовує та оцінює його.

Таким чином визначені наукові підходи та загально дидактичні та специфічні принципи навчання стали підгрунтям розробки структурно-компонентної моделі формування професійної компетентності майбутніх бакалаврів харчових технологій у процесі вивчення фахових дисциплін.

\section{4. Обгрунтування моделі формування професійної компетентності}

Структура моделі формування професійної компетентності майбутніх бакалаврів харчових технологій, яка забезпечує досягнення очікуваних результатів, представлена низкою компонентів:

1) цільовий, що охоплює мету, підходи та принципи; 
2) організаційно-змістовий, обгрунтований структурою та змістом формування професійної компетентності майбутніх бакалаврів харчових технологій та об'єднує педагогічні умови, форми, методи й засоби забезпечення педагогічного процесу з формування професійної компетентності майбутніх бакалаврів харчових технологій;

3) рефлексивно-результативний, що містить критерії, рівні та показники результатів.

Кожна складова моделі є невід'ємною їі частиною і характеризується сукупністю відповідних засобів, форм і методів навчання (рис. 1).

Цільовий блок передбачає висвітлення мети - формування професійної компетентності майбутніх бакалаврів харчових технологій у процесі вивчення фахових дисциплін, що здійснюється з урахуванням вищеозначених наукових підходів. Вона полягає у створенні системи заходів щодо підвищення рівня професійної компетентності майбутніх фахівців, спрямована на реалізацію педагогічних умов та визначається соціальним замовленням на професійно компетентних фахівців, здатних до професійної діяльності у ПТНЗ, на підприємствах харчової галузі та у сфері обслуговування.

Відповідно до мети сформульовано основні завдання цього процесу: створення стійкої мотивації, систематизація набутих знань, формування стійких професійних вмінь та навичок, здатності до рефлексії.

Організаційно-змістовий блок охоплює педагогічні умови, педагогічні технології, форми, методи та зміст навчання майбутніх бакалаврів харчових технологій у процесі вивчення фахових дисциплін.

Серед педагогічних умов, які сприяють формуванню професійної компетентності майбутніх бакалаврів харчових технологій у процесі вивчення фахових дисциплін, нами виділено такі:

- створення мотиваційно-ціннісного середовища в навчальному процесі задля вироблення у студентів ціннісного ставлення до опанування фаху фахівця-технолога харчових технологій;

- спрямування майбутніх бакалаврів харчових технологій на розширення когнітивно-діяльнісного складника професійної підготовки через використання інтерактивних методів навчання;

- розвиток професійно важливих здібностей (інтелектуальних, організаторських, комунікативних та ін.), морально-етичне вдосконалення особистості фахівця, розвиток його індивідуальності тощо.

Розглянемо ці педагогічні умови більш детально. 


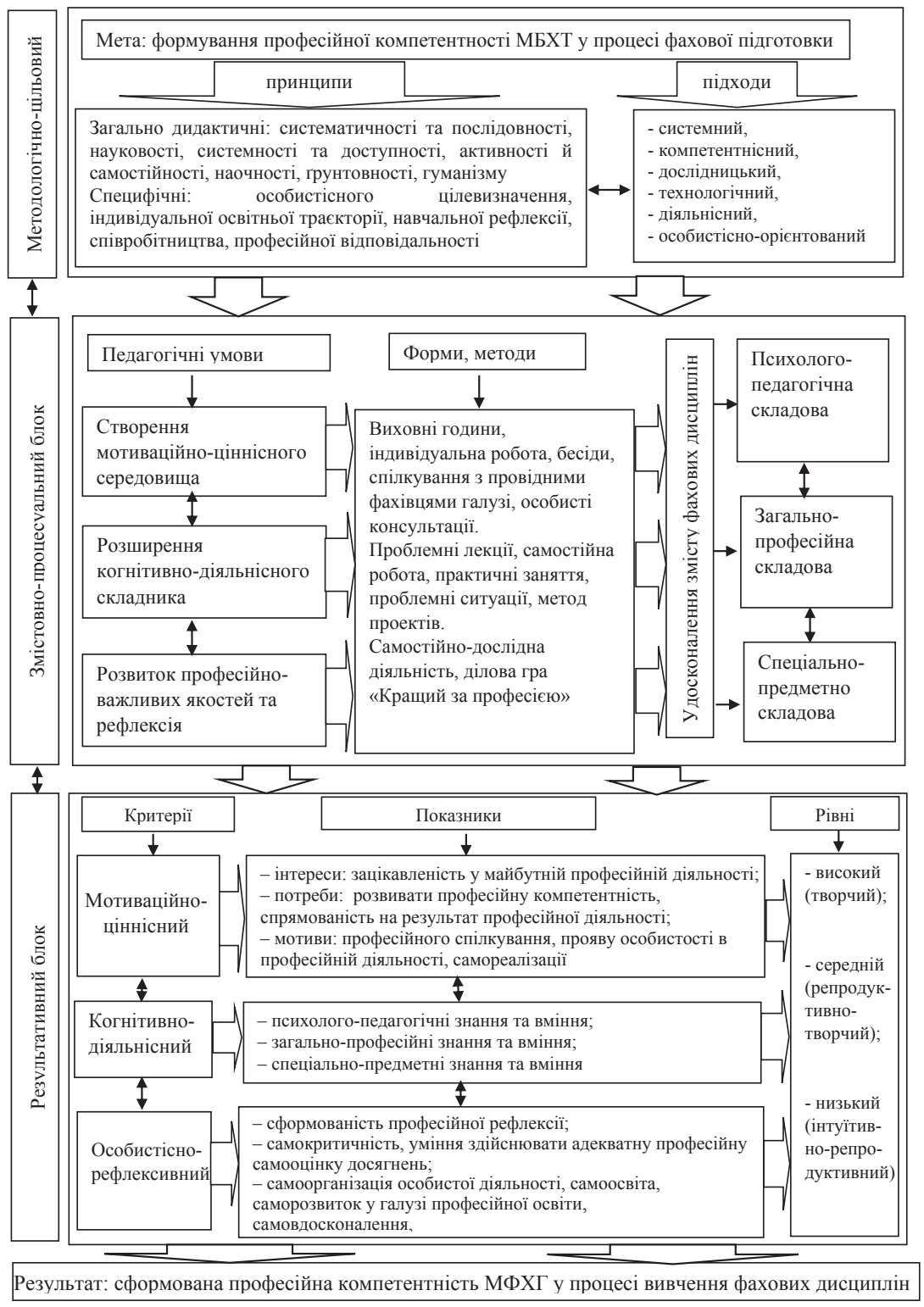

Рис. 1. 
Реалізація першої педагогічної умови зі створення мотиваційно-ціннісного середовища в навчальному процесі задля вироблення у студентів ціннісного ставлення до опанування фаху викладача спецдисциплін у галузі харчових технологій, майстра виробничого навчання, можлива через виконання індивідуальних та самостійних завдань професійного змісту, спрямованих на розвиток мотивації студентів та виховання свідомого ставлення до майбутньої професійної діяльності.

У процесі наукового пошуку доведено, що під час вивчення фахових дисциплін доцільно розвивати інтереси (зацікавленість бакалаврів у майбутній професійній діяльності, усвідомлення іiї суспільної значимості та престижу), виховувати потреби (розвивати професійну компетентність, поглиблення теоретичних знань та удосконалення практичних навичок), формувати мотиви самоствердження, саморозвитку та самореалізації.

Реалізація другої педагогічної умови здійснювалась у процесі вивчення фахових дисциплін «Технологія виробництва продукції громадського харчування», «Виробниче навчання», «Ресторанна справа» за рахунок створення і реалізації цілісного навчально-методичного супроводу 3 використанням інтерактивних технологій. Для ефективної професійної діяльності в закладах профтехосвіти майбутній бакалавр харчових технологій повинен оволодіти системою знань та умінь. Основними професійно-значущими є знання 3 дисциплін психолого-педагогічного, загально-професійного та спеціально-предметного спрямування, які закріплюються та корегуються в процесі практичної діяльності, формуючи уміння та навички. Їх сформованість в свою чергу сприяє розвитку уміння трансформувати технічні знання у педагогічну систему навчання учнів ПТНЗ, що $є$ для майбутнього бакалавра специфічним та пріоритетним завданням.

Формування та ефективна реалізація умов позитивної мотивації суб'єкта до майбутньої професійної діяльності, а також розширення когнітивно-діяльнісного складника освітнього процесу сприятимуть розвитку особистісних та професійних якостей особистості, що визначають третю педагогічну умову. Провівши попередні дослідження, ми виокремлюємо найбільш значущі, на нашу думку, особистісні (моральні, інтелектуальні) та професійно-важливі (комунікативні, організаторські, творчі) якості майбутнього бакалавра харчових технологій. 
Варто зазначити, що визначені педагогічні умови формування професійної компетентності майбутніх бакалаврів харчових технологій реалізуються комплексно, оскільки взаємопов'язані між собою та базуються на використанні компетентнісного підходу у підготовці студентів у вищих педагогічних навчальних закладах.

Реалізацію мети й завдань формування професійної компетентності майбутніх бакалаврів у запропонованій моделі забезпечують форми (лекції, практичні та лабораторні заняття, індивідуальна та самостійна робота, самоосвіта) і методи (проблемне викладання навчального матеріалу, дискусія, евристичні методи, ділова гра, круглий стіл, метод проектів, моделювання, розв'язання педагогічних задач) навчання шляхом моделювання умов, змісту і динаміки реального виробництва та відносин залучених у ньому людей.

Передбачається, що навчальні заняття та самостійна робота студентів проводяться з використанням педагогічних технологій інтерактивного, проблемного навчання, проектної, тренінгової та нових інформаційних технологій. 3 метою формування професійних навичок студентів у межах фахових дисциплін особливу роль відіграють зустрічі та контакти 3 працівниками професійної освіти, провідними фахівцями харчової галузі, інтерактивні форми проведення занять, а також майстер-класи i тренінги майбутніх фахівців. Зміст роботи, спрямованої на формування професійної компетентності майбутніх бакалаврів, охоплює фахові дисципліни «Технологія виробництва продукції ресторанного господарства», «Виробниче навчання», «Ресторанна справа», «Методика професійного навчання» та самостійну роботу студентів.

Виокремлені нами методи навчання передбачають активну взаємодію викладача та студентів, активізують розумову та пізнавальну діяльність студентів, сприяють позитивній мотивації до майбутньої професійної діяльності, потребують самостійного конструювання знань та орієнтації в інформаційному просторі. Такі методи навчання сприяють збудженню інтересу студентів до нових досягнень науки та техніки, роблять процес навчання цікавим. У процесі вивчення фахових дисциплін студенти оволодівають реальним досвідом виконання професійних завдань. При застосуванні таких методів викладачі, від педагогічного досвіду яких залежить якість узагальнених професійних умінь студентів, виступають у ролі колег та корегують і направляють дії студента у відповідному напрямку. 
Запропоновані технології, методи та форми навчання, за нашим припущенням, будуть сприяти, за умови їх реалізації, засвоєнню навчального матеріалу дисциплін психолого-педагогічної, загально-професійної та спеціально-предметної складової структури професійної компетентності.

У рефлексивно-результативному блоці передбачено оцінювання, аналіз та корекцію результатів формування професійної компетентності майбутніх бакалаврів харчової галузі. У ньому відображено критерії (ціннісно-мотиваційний, когнітивно-діяльнісний, рефлексивний), їхні показники та рівні сформованості.

Мотиваційно-ціннісний критерій $є$ основою формування професійної компетентності майбутніх фахівців харчових технологій і характеризується їх ставленням до педагогічної професії. Від сформованості цього критерію залежить ступінь активності майбутніх фахівців харчових технологій як суб'єктів професійної діяльності, їх прагнення розвивати професійну компетентність, мотивація до самореалізації.

Спрямованість, інтенсивність, стійкість, дієвість мотивів визначають успішність оволодіння професійною діяльністю, ефективність іiі практичної реалізації, задоволення працею й прагнення особистості до самовдосконалення та професійного розвитку.

Характеризуючи мотиваційно-ціннісний критерій професійної компетентності майбутніх фахівців у галузі харчових технологій, дослідники відзначають такі показники його сформованості: потреба в досягненні успіху у професійній діяльності, позитивна мотивація студентів до організації навчально-виховного середовища професійно-технічного навчального закладу, потреба у професійному зростанні.

До показників мотиваційного критерію відносимо:

- інтереси: зацікавленість майбутніх бакалаврів харчових технологій в опануванні професійною діяльністю;

- потреби: потреба розвивати професійну компетентність, спрямованість на результат професійної діяльності;

- мотиви: мотив професійного спілкування, мотив прояву особистості в професійній діяльності, мотив самоактуалізації.

Отже, сформований мотиваційний компонент професійної компетентності майбутнього фахівця як результат його підготовки до професійної діяльності забезпечує ефективність подальшого становлення компонентів компетентності і передбачає: інтереси, потреби, мотиви. 
Майбутні бакалаври харчових технологій допомагатимуть учням оволодіти сучасною технікою і технологіями харчового виробництва, передовими методами праці, а також формуватимуть основи професійної майстерності. Для ефективного здійснення своїх функцій вони повинні бути готовими до розв'язання педагогічних і фахових завдань у навчально-виховному процесі закладу профтехосвіти, тобто володіти високим рівнем професійної компетентності [10, с. 64]. Саме у когнітивно-діяльнісному критерії відображено рівень їх теоретичної та практичної підготовки, який відображає як інтелектуальну сферу майбутніх фахівців, так і рівень їх практичної підготовки, тобто систему вмінь і навичок, які забезпечують виконання дій та операції, визначених в основі професійної діяльності.

Поняття «уміння» та «навички» мають значну кількість дефініцій у науковій та довідковій літературі, проте автори єдині у тому, що ці категорії відображають рівень оволодіння діяльністю, дією та операцією. Вважаємо, що у теорії й методиці професійної освіти уміння варто розглядати як компетентне здійснення професійних дій, навички - здійснення операцій, які покладені в їх основу, тоді система умінь та навичок майбутнього фахівця формує компетентність виконання професійної педагогічної діяльності як цілісної системи.

Одним із основних показників когнітивно-діяльнісного компоненту професійної компетентності вважаємо таку систему знань та вмінь:

- психолого-педагогічні знання та вміння (формування мотивації учіння, організація навчально-професійної діяльності учнів, вибір оптимальних засобів педагогічного впливу, планування організації навчально-виробничого процесу учнів і контролю за їх навчально-виробничою діяльністю, оцінювання професійного саморозвитку майбутніх бакалаврів харчових технологій);

- загально-професійні знання та вміння (обгрунтовування навчальних планів, обсяг і зміст програм дисциплін та виробничої практики; розроблення нових навчальних курсів на базі розвитку нових наукових напрямів з урахуванням умов сучасного виробництва та ін.);

- спеціально-предметні знання та вміння (уміння вирішувати типові та нетипові завдання, які виникають у процесі реалізації своїх компетенцій; наявність практики професійної діяльності та ііі результат, що відображає рівень оволодіння професійною компетентністю на певному етапі iї формування та ін). 
Отже, когнітивно-діяльнісний компонент професійної компетентності майбутнього бакалавра харчових технологій визначає рівень опанування вищезазначеною системою знань та вмінь, що, на нашу думку, забезпечить формування здатності фахівця у майбутній професійній діяльності реалізовувати завдання психолого-педагогічної, загально-професійної та спеціально-предметної складової професійної підготовки на засадах компетентнісного підходу.

Проте обмежувати професійну компетентність майбутніх бакалаврів харчових технологій тільки знаннями й уміннями видається недоцільним, адже для їхньої ефективної педагогічної діяльності не менш значущими є індивідуально-психічні, особистісні й професійно важливі якості, що сприяють успішності їх професійної діяльності.

Саме це відображено в особистісно-рефлексивному критерії, який визначає рівень розвитку самооцінки, здатність фахівця адекватно оцінювати власні досягнення в галузі професійної освіти, свій рівень професійної компетентності, прагнення до самореалізації, саморозвитку, постійної роботи над собою у галузі професійної освіти та харчових технологій, уміння аналізувати ефективність методів, прийомів, засобів педагогічної діяльності та технологій, відповідальність за результати своєї діяльності.

Для даного критерію ми визначили наступні показники сформованості професійної компетентності:

- сформованість професійної рефлексії;

- самокритичність, уміння здійснювати адекватну професійну самооцінку досягнень;

- самоорганізація особистої діяльності;

- самоосвіта, самовдосконалення, саморозвиток у галузі професійної освіти.

Особистісно-рефлексивний критерій є показником власної активності майбутніх бакалаврів з усвідомленням своїх дій, особистісних i професійно важливих якостей, рівня свого професійного розвитку та самовизначення. Він відображає усвідомлення шляху, методів і результату професійно-особистісного розвитку.

Отже, розроблена модель формування професійної компетентності майбутніх бакалаврів харчових технологій становить комплексну структуру, що складається із взаємопов'язаних елементів і компонентів та орієнтована на майбутню професійну діяльність. Реаліза- 
ція такої моделі забезпечує цілеспрямоване формування визначених знань, умінь і навичок, а отже, сприятиме сформованості професійної компетентності у процесі вивчення фахових дисциплін.

Таким чином результатом реалізації моделі є розвинуті:

- ціннісні орієнтації майбутніх бакалаврів на формування їхньої готовності до професійної діяльності;

- узагальнені професійні знання та вміння, що створюють основу для формування професійної компетентності майбутнього фахівця;

- сформовані особистісні якості майбутнього бакалавра харчових технологій.

\section{5. Висновки}

Модель формування професійної компетентності майбутніх бакалаврів харчових технологій у процесі вивчення фахових дисциплін представлена як інтегрована система цілісного процесу професійної підготовки до майбутньої професії, яка містить шляхи досягнення поставленої мети на основі застосування різних форм і методів навчання та через реалізацію педагогічних умов.

Структурно-компонентна модель, як один 3 компонентів системи професійної підготовки, відображає сукупність можливостей освітнього та матеріально-просторового середовища, впливає на особистісний і процесуальний аспекти даної системи, і забезпечує іiі ефективне функціонування і розвиток. Її обгрунтування та реалізація, на нашу думку, сприятиме вдосконаленню особливостей освітнього процесу та оптимізації професійної підготовки майбутніх бакалаврів харчових технологій у вищих педагогічних навчальних закладах.

\section{Список літератури:}

1. Common European Principles for Teacher Competences and Qualifcations. Education and Training 2010 - The Success of the Lisbon Strategy Hinges on Urgent Reforms, http://ec.europa.eu/education/policies/2010/doc/principles_en.pdf

2. The Bruges Communiqué on enhanced European Cooperation in Vocational Education and Training for the period 2011-2020. - European Ministers for Vocational Education and Training, 2010. -19 p.

3. Бібік Н. М. Компетентнісна освіта - від теорії до практики / Н. М. Бібік, I. Г. Срмаков, О. В. Овчарук. - К. : Плеяда, 2005. - 120 с.

4. Гриневич Л. Професійно-технічна освіта - це частина національної безпеки країни / Л. Гриневич // Професійно-технічна освіта. - 2016. № 2. - C. 4-7. 


\section{Professional competence formation model of the future bachelors of food...}

5. Добровольська О. В. Формування соціально-особистісних компетенцій бакалаврів напряму підготовки «Харчові технології та інженерія» інтеграцією аналітичної хімії та історії їі розвитку / О. В. Добровольська // Модернізація вищої освіти та проблеми управління якістю підготовки фахівців : VIII Всеукр. наук.-метод. конф., 23 вересня 2010 р. / ред.кол.: О. І. Черевко [та ін.]. - Харків : ХДУХТ, 2010. - С. 47-49.

6. Коваленко О. Е. Теоретичні засади професійної педагогічної підготовки майбутніх інженерів-педагогів в контексті приєднання України до Болонського процесу : монографія / О. Е. Коваленко, Н. О. Брюханова, О. О. Мельниченко. - Харків : УІПА, 2007. - 162 с.

7. Національна стратегія розвитку освіти на 2012-2021 рр. [Електронний pecypc]. - Режим доступу: http://www.mon.gov.ua/images/files/news/12/4455.pf].

8. Сичевська Н.С. Формування фахової компетентності майбутніх техніків-технологів у процесі вивчення професійно орієнтованих дисциплін : дис. ... канд. пед. наук : 13.00.04 «Теорія і методика професійної освіти» / Наталія Сергіївна Сичевська // Нац. пед. універ. імені М. П. Драгоманова. - Київ, 2012. - 274 c.

9. Тархан Л.3. Теоретичні і методичні основи формування дидактичної компетентності майбутніх інженерів-педагогів : автореф. дис. на здобуття наук. ступеня доктора пед. наук : спец. 13.00.04 «Теорія і методика професійної освіти» / Лєнуза Запаївна Тархан. - К., 2008. - 40 с.

10. Юртаєва О. О. Розвиток професійно-педагогічної компетентності майстрів виробничого навчання будівельного профілю в системі післядипломної педагогічної освіти : дис. ... канд. пед. наук : 13.00.04 / Ольга Олексіївна Юртаєва. - К., 2011. - 366 с.

\section{References:}

1. Common European Principles for Teacher Competences and Qualifcations. Education and Training 2010 - The Success of the Lisbon Strategy Hinges on Urgent Reforms. Available at: http://ec.europa.eu/education/policies/2010/doc/ principles_en.pdf

2. European Ministers for Vocational Education and Training (2010) The Bruges Communiqué on enhanced European Cooperation in Vocational Education and Training for the period 2011-2020. Belgian: European Ministers for Vocational Education and Training.

3. Bibik N. M., Ovcharuk O. V., Yermakov N. M. (2005) Kompetentnisna osvita - vid teoriyi do praktyky [Competence education - from theory to practice]. Kyiv: Pleyada (in Ukrainian).

4. Grynevych L. (2016) Profesijno-tehnichna osvita - ce chastyna nacionalnoyi bezpeky krayiny [Vocational and technical education is part of the national security of the country]. Profesijno-tehnichna osvita, vol. 2, pp. 4-7.

5. Dobrovol`s`ka O. V. (2010) Formuvannya social’no-osobystisny`h kompetencij bakalavriv napryamu pidgotovky' "Harchovi tehnologiyi ta inzheneriya" integraciyeyu anality chnoyi himiyi ta istoriyi yiyi rozvy` tku [Formation of social personal competences of bachelors of specialty "Food technologies and engineering" by integration of analytical chemistry and history of its development] 
Proceedings of the Modernizaciya vy 'sh hoyi osvity ta problem upravlinnya yakistyu pidgotovky fahivciv (Ukraine, Harkiv, September 23, 2010) (eds. Cherevko O. I.), Harkiv: HDUHT, pp. 47-49.

6. Kovalenko O. E., Bryuhanova N. O., Mel`ny`chenko O. O. (2007) Teorety 'chni zasady profesijnoyi pedagogichnoyi pidgotovky majbutnih inzhenerivpedagogiv $v$ konteksti pry yednannya Ukrayiny" do Bolons "kogo procesu [Theoretical bases of professional pedagogical preparation of future engineers-teachers in the context of Ukraine's accession to the Bologna Process]. Harkiv: UIPA. (in Ukrainian)

7. Nacional 'na strategiya rozvy'tku osvity na 2012-2021 rr. (2010) [National Strategy for the Development of Education for 2012-2021] Available at: http://www.mon.gov.ua/images/files/news/12/4455.rf.

8. Sy`chevs'ka N.S. (2012) Formuvannya fahovoyi kompetentnosti majbutnih texnikiv-tehnologiv u procesi vy`vchennya profesijno oriyentovany`h dy`scy'plin [Formation of professional competence of future technologists in the process of studying professional disciplines]. Kyiv: NPU im. M. P. Dragomanova. (in Ukrainian)

9. Tarhan L.Z. (2008) Teorety 'chni i metody 'chni osnovy` formuvannya dy'dakty'chnoyi kompetentnosti majbutnih inzheneriv-pedagogiv [Theoretical and methodological foundations of the formation of didactic competence of future engineers-teachers]. Kyiv. (in Ukrainian)

10. Yurtayeva O. O. (2011) Rozvy`tok profesijno-pedagogichnoyi kompetentnosti majstriv vy`robny'chogo navchannya budivel’nogo profilyu v sy`stemi pislyady 'plomnoyi pedagogichnoyi osvity' [Development of the professional pedagogical competence of the masters of the production training of the building profile in the system of postgraduate pedagogical education]. Kyiv. (in Ukrainian) 